\title{
Third Place
}

\section{MAHSA ZAMIRI and MOHAMAD REZA ZAMIRI}

\author{
Lecturer in Urban Planning, University Of Bojnord, Bojnord, Iran.
}

http://dx.doi.org/10.12944/CWE.11.Special-Issue1.04

(Received: July, 2016; Accepted: August, 2016)

\begin{abstract}
Third place is not house either workhouse. It is a place between two places for visiting with friends, resting and drinking without any stress. Roy Oldenburg defines third place in this way: third places are the places which people can be together in it and communicate. Inverse, first place (house) and second place (work house) allow to people that be together and enjoy of speaking and being together. Streets corners, coffee nets, coffee shops and other third places are the base of people highlighted attendance as heart of live societies.
\end{abstract}

Keywords: Third place, Public space, Social behavior.

\section{INTRODUCTION}

City is the most clear aspect of human need for social life which formed from sum relations between people with each other and with their around environment. Principally, a city is alive and dynamic where experiences, demands and its habitants appear in it. The city can allows to its habitants to see each other and percept attendance sense in a active urban environment, shoulder to shoulder and age to age .this chance, best place for appearing, will be attain in public place. The public places allow to citizen to attend, active and use, and provide a situation for him where can use the places to make social relation in best form. Cultural and social inter changes and discussion about urban problems occurs in such places.

Urban place is one of factors to construct urban place which created, formed and changed along with history of a nation in different periods. These factors which always have beaten with heart of urban history and have written urban narration and cultural, social, economic or political different activities have continued always in there. Off course this subject that valuable urban places belong to past do not mean not to be in need to such places in modern cities. It should be used the spaces which are alive and public and urban movements occur in it ${ }^{1}$.urban place mean to the place belongs to all people who in flounced by it or effect on it. This place is available for all people and used commonly. for example, the public street belonging and connected to all people as a totality, is open for them, has unlimited existence, presented by government and related to it urban place is a common ground where done functional activities and the ceremony links community members to each other whether daily activities or periodical festivals ${ }^{2}$. Urban place allows the people access to it and secured and administered for public benefits.

Rey Oldenburg in his book as "The great good place" refers to this point that modern cities are down falling and social activities have decreased in urban places .he argue that this problem caused by suburb anal development after universal second war, families re location increment Urban ace is one of factors to construct urban in city, dependence increment to core, freeway development one functional regional division of cities which cause to form invaluable places socially. Suburbs and urban sectors disability in creation of social places for their habitants have isolated individuals and families. 
Citizens see each other only in peripatetic while they don't know each other. Generally face to face relations has been reduced and mutual relations and activities are deleting the urban life a place is good if it cause to approach the people to each other, increment of their friendship ,people encouraged to sitting, relaxation and speaking there. "A good place is the place that you been seen well and see comfortably. People want to see what do other persons?"[Ray Oldenburg] ${ }^{3}$.

\section{Problem explanation}

Urban place means to a place which belongs to all people who influenced by it and effect on. This place is available for all people and used commonly. For example the public street belonging and connected to people as a totality, is open for them has unlimited existence, presented by government and the ceremony links community members to each other whether daily activities or periodical festivals ${ }^{4}$.urban place allows the people access to it and accomplished activities there. It is a place which controlled by a public organization and secured and administered for public benefits. Urban place has been inseparable part of urban special construct in different periods of urban history, therefore has been followed of economic and social conditions as a general urban construct. It has appeared in different shapes such as square, street, house of ta'zy-e, market, passage and etc ${ }^{5}$ all people's optical and physical balanced access is one of the urban place traits. In other words, this urban place is like as the page where opened collective life story.

It can't be known every kind place in urban as an urban place, so special optical and motive relations with special traits create urban place. Gordon Cullen who is the one of first theorists about structural order between component and environment, believes to an art beyond of architecture in urban, this art is based on relation. "Components combination such as building, nature, traffic, advertisements and etc. make a product which domination on the set planning is possible by relying on communication concept "he says.

The relation between formative components of urban place should be comprehensible for person and he be able creates a construct of current relation in his mind .therefore urban place is purposed and will be a ground for defined events in this place, there is an opportunity to happen affects which haven't been edited before, and people confabulate with each other in social space. So, establishment of social relations is the main provision for being urban of a public place. According to what stated, artificial urban place is organized, natty and ordered as a ground for human behaviors and activities. Human is a component of this place and gives meaning and concept to this place by his values and norms ${ }^{6}$

\section{Where is third place}

The cities are filled of individuals who have important, useful, enlivening and meaningful relations. If friendship relations and other formal familiarity limited to individuals 'private life, the cities frustrated and adding social life to them is necessary $^{7}$

Ray Oldenburg has many writing informally about public and collective places importance. He refers in his book to this point that how these places help to make social and public places. He believes that coffee shops, public stores, and other third places (inverse of first and second places or house and housework) are the centers of creating communities and people highlighted present and livability increment.

Oldenburg believes that there is not enough satisfactory and comfy urban places in cities and sectors today. Adjacency and closing to a place which be appealing and also amplify social sodality is a requirement tool for moral and spiritual health. Indeed citizenship and social sense formed in third places. Third place overrides on first and second places, because in third place, attendance is arbitrary and informal, and happy and ordered environment and a more desirable place is available for users $^{8}$

Key traits of third place consist of:

Third place is a place to fulfill human social requirements. It is surprising that has been paid less attention to advantages of this kina place.

-it is a place where people see each other that makes happy sense in persons. The activities done in the place have not been pre organized and pre planned. 
- $\quad$ Third place is the place where people speak to improve each other honestly and help to improve the others people.

- $\quad$ Third place is a place for being relieved of daily works.

- $\quad$ Third place develops public associations which are decreasing nowadays.

- $\quad$ Third place provides an opportunity to present important discussions and wrangles.

Third place creates democracy experiences for people and amplifies self-confidence sense. It helps to make and establish social equity.

- $\quad$ People daily problems and concerns forgotten in third place.

- $\quad$ Third place is difference from daily life, and well known by comparing. It isn't used to show house and workhouse badly. This comparison used to clear better the public places ${ }^{9}$

Distinctive and fixed users are one of third place properties. Livability and happiness are marks

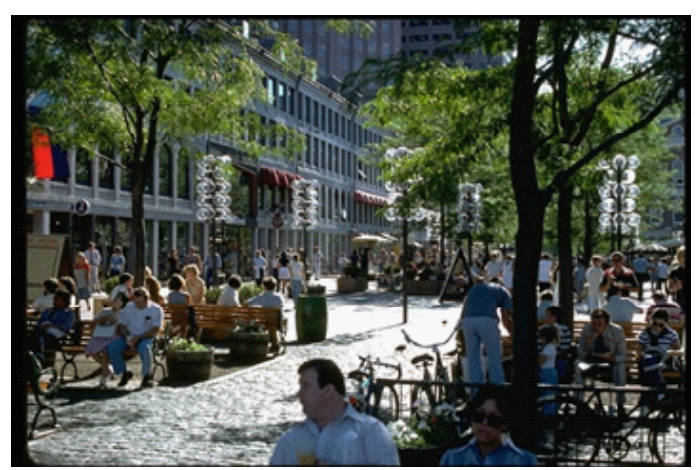

Fig. 1: active urban space, France

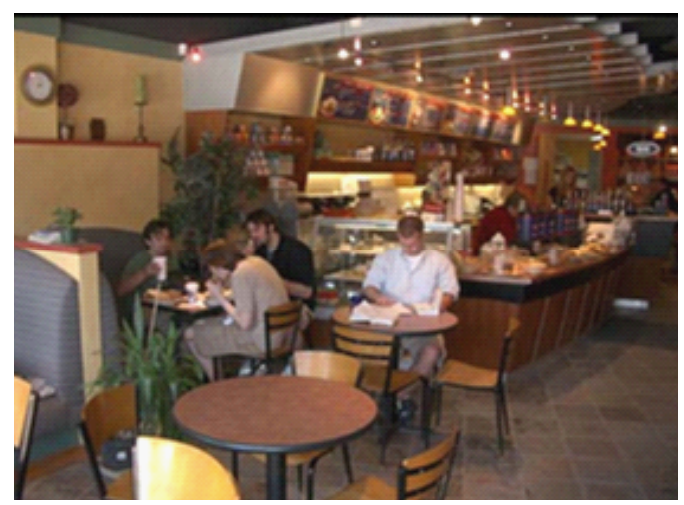

Fig. 2: Coffee shop as third place of these places. Inverse, people do important and serious activities in other action places. Third place is very similar to a dreamlike house which makes calm and convenience sense in individuals. in summary, streets and shopping centers have been filled out of people who don't know each other and are strange with together. So that the people who are walking in a fixed and distinct route (invariable stream of pedestrian and galloping traffic) don't see a familiar. Such routes are very drowsy and spiritless for walking. Most third places created in urban centers so that all habitants can use these places. But these places often haven't ability to collect people and provide the ground for their attendance.

Irwin Altman in his book" environment and social behavior" divides people personal territory to three classes: the first is primary territory which owned and used exclusively by special person or group. It always adopted by individuals and these territories have basic role in their daily life. Second is secondary territory that has less central and exclusive role and is equivalent with secondary groups in social science. For example there is a formal or informal limitation in local coffee shops, clubs and social associations that indicates who can use the local or territory.

Altman construes local coffee shops as secondary territory and refers that local coffee shops have diverse customers or users such as: fixed customers, time to time customers and different groups who go to coffee shop in different hours of day. Fixed customers have distinct place in most cases, and use coffee shop for different works such as financial works, receiving and reading the letters,

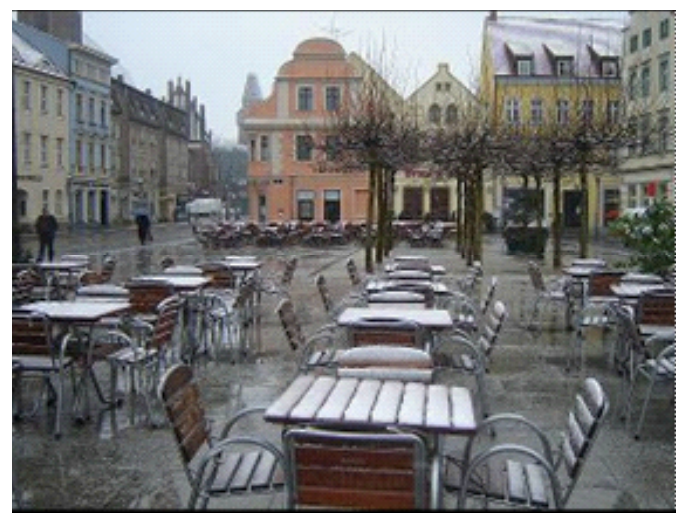

Fig. 3: Italian Faberna 
and for calling. Indeed fixed customers assume coffee shop as their personal territory and sometimes look at strangers as an aggressive. Third place is public territory which is temporal, available and useful for everyone. This kind of territory is a brittle and changeable mechanism to supervise on border between itself and others. The territory depends to custom and social norms. With regard to considered defines for third place, third territory there is in third places. For example, table and chair in restaurant considered as public territory until customers use it $^{10}$

From other looking, Oldenburg introduces eight traits of third places in this follow:

-they are neuter places.

-individuals' degree and social position is unimportant or less important in these places.

-they are available comfortably.

-speaking is most important activities in these places.

-the places are simple and without flamboyance.

- There are happiness and livability in the places.

-the places create attendance sense at home, without being at home ${ }^{11}$

\section{Third place: a place for every one}

Every one may has some friends and opportunities to communicate with them. Friends group can be big. The groups can meet each other in such places.

Richard Sennet believes that persons can be socialized and enter into society only when

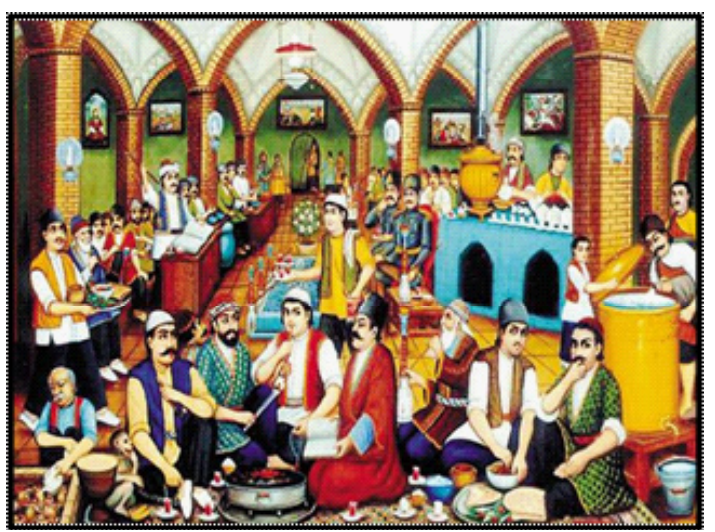

Fig. 4: Coffee houses in Iran be protected by other persons. The sense created in third places. Making participation, moral and reinforcement of dependency to place sense is basic trait of third place. Consensuses believe that third place position has been reduced in modern lives.

Third place makes close relation between urban locals and citizens. Deletion the places from urban life, reduces face to face relations and local people don't aware from each other, in spite of living together for many years. Cities and neighborhood units have the potential to create neutral place according to public request. As whatever there is at home, the places should create secure and calm sense. If the places be taken from neighborhood units where there is citizens' life, groups and social associations are unaffected and disnatured out of house environment, neighbors will not meet each other and made any speaking between them, because there isn't a place for them to accession these behaviors.

Social correctors have rarely considered importance of the centers and mutual relations and social activities. Some of them didn't like to see people in pavement, streets, supermarket, in forward of sweetshop stairs and doorway, and other public centers. They like that people be in private places and don't their time in public places.

\section{Third places kinds}

It should be passed from time borders to study and recognize third places. For example Arab coffee shops, German bierstube, Italian Faberna, stores of American ancient suburbs are examples of third places.

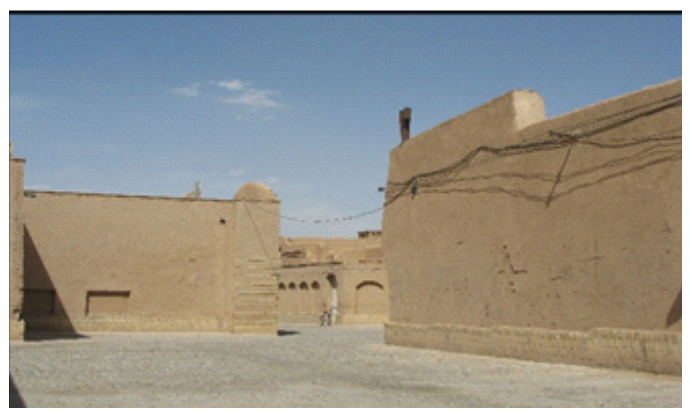

Fig. 5: Impasse in historical neighborhood, Yazd, Iran 
Wechsberg believes that the coffee shops which have rest room, study hall and gaming house, numerated as third place in vie an. off course he and Menken present limit and small conception of third place. While it should be look at third place by a more galactic looking ${ }^{12}$ Oldenburg believes that, societies and figurative places help to decline the third place and act as a replacement for these places in modern life. Indeed, these figurative places cause to remain the people at their homes and don't present in streets and third places ${ }^{13}$ Nowadays, extent of social relations, face to face contacts and subsequently citizen's urban and social life are declining, because of society's industrialization, extension of electronic relations, and increment of time presence at home.

\section{Examples of third place in Iran Haunt as a third place}

Indeed haunts are contour between personal house and workhouse. A person doesn't like house calm and society crowd. In the past, in more cases experiences show that haunt are small aggregation centers which stand in cozy and calm places or they had planned somehow, they could developed particular and calm places, moreover they settled on index point of urban. Most of them aren't very big, of scale. Their position in great view perspectives removes calm sense of them. Moreover to being semi-gloss of facades, factors such as having a comfortable and sustainable for long hour's furniture, smooth light, music if possible calm and classic music and such like, can effect on dependency sense. Calm, grace and sometimes forget are whatever make a haunt more absorbing for its customers ${ }^{14}$

\section{Coffeehouse}

Explanation of coffee shop word has come in Persian encyclopedia second case in this follow; coffeehouse is a place that had drank tea there and after propagation of tea, this potable obtained his place, but coffee shop title remained.

In social history of Tehran in century $13^{\text {th }}$ by Jafar Shahri, coffeehouse definition has come in this follow: coffeehouse was one of Tehran people play grounds, where absorbed all individuals groups toward itself and provided for every class, themselves amusement and plays. It was provided the cases such as minstrelsy, performance of verses and song sting meetings, and sometimes "eloquent" circle. The mentioned book states about coffeehouse appearance, in this follow: covered coffeehouses had big brumal halls which had carpeted by rug, durries rug and wad. Door, wall column and roof had decorated by different curtains, picture and images and skin, battleaxes; dervishes bowl even banner, hillock and flags along with canorous birds which show the environment more attractive ${ }^{15}$

Coffeehouse was place that men went to there in their leisure to drink the tea, exchange opinions, aware of news, placement, trade and listen to epopee stories which performed by minstrel continually every night. Coffeehouse changed to a stamping ground for literati from beginning in Iran and many of authors, poets and other artificer averted some hours of their time in coffeehouse and read their writings and works for audience with regard to limitation of mass media and publication media. Every coffeehouse had special customers separate of its building which was same as other coffee house building, and as it is yet current, main customers of coffee shops consisted of free services profession owners. Every coffee shop was a haunt and an association place of a caste. On that time, Coffee shop was used to arbitration and dispose local problems and sometimes familial problems ${ }^{16}$

In the past, coffee shop was a cultural and special institution and an academy and a school for literary and artificial training and teaching the traditional culture and literature to masses of people. But coffee shop lost its value and credibility gradually during the time and along with extension of audio visual communication system in urban community and radio and TV entrée. Ali Blookbashi, author of "coffeehouses of Iran" book writes about there: coffeehouses that were center of publication and cultivation of our past generations' literary and artistic achievements and traditional culture. It undertaken important role in social communications order and collective credence, survival of Iranian Islamic cultural values among difference groups and classes of people particular burgher communities, gradually changed to a place for drinking tea and having breakfast, lunch and to rest. Also some of them changed to corruption centers and iniquity, evildoing and misleading publication. In this time, coffeehouses busted their cultural junction bonds 
with past and past generation traditions, and kept aloof from past useful function.

\section{Impasses in locals}

Impasses connect residential units to public places in old locals of Iran cities. They were a place for intersection and contact or for sitting down residents, and passes had allowed very close neighborhood relations. Passes also provided security and intimation for some present family in passes $^{17}$

\section{CONCLUSION}

How can live in human space yet using of technology profit? This is the basic question that famous urban and architectural planners are following its answer for half century. All of them agree that standards and rules forming past places should be recognized and received instruction by others. Ancient urban place is the best laboratory to learn and understand ${ }^{18}$

Exact looking to space planning experience during the history is the best way for perceiving the urban space. Edmund Bacon believes that studying essence of architectural and urbanism valuable works is special trait.

In fact spatial properties consider as heart of cultural and social relations and social activities in cities. Today, industrializing societies and developing electronic communications and increasing presence in home cause reducing social encounters and face to face contacts and lead to weaken social life in cities.
The third places increasingly has attained its long lost importance in urban design and planning in western cities. In Iran traditional coffee houses and stamping grounds, and urban squares or old passages were urban spaces with social life. These places replaced with modern coffee shops and restaurants (which cannot be considered as traditional spaces). These places have low quality of social life and other urban qualities.

Our present urban neighborhoods have less and rare open or social oriented spaces to response needs of citizens. Spaces which had such function, has obsoleted or in much cases destroyed.

Properties of such places which considered as third places have to study and notice then adapt with needs of today cities to revive third places in contemporary urban areas. These properties are:

- $\quad$ Neutrality of space

- $\quad$ No significant or negligible social position of people

- Accessibility

- $\quad$ A place to truly conversation

- $\quad$ Simplicity of place

- $\quad$ Flowing life in place

- Sense of hilarity and jubilation

- $\quad$ Sense of peace

- ...

According to above, semiprivate places which are fading out in contemporary lifestyle, have enough capability to make third places. For instance: coffee shops, restaurants etc. Accommodating traditional places with present needs and socializing existing spaces in cities may resurrect third places and revive social life in our cities.

\section{REFERENCES}

1. Tavassoli,M \& Bonyadi,N. 1992. Urban space design1. Center of motale'at \& tahghighat shahrsazi \& memari, Tehran, Iran.

2. Madani poor, A.2000. Urban space design. Pardazesh \& barname rizi center, Tehran,Iran.

3. Coburn, B. 2006. Cafés of community: the Starbucks principle. Strategic Adult Ministries Journal (Vol. 18, No. 5, Issue 145), 8-9.8-9.
4. Madani poor, A.2000. Urban space design. Pardazesh \& barname rizi center, Tehran,Iran.

5. Pakzad, J. 2006. Urban space design guidance. Maskan \& shahrsazi department, Iran.

6. Arbab, P. 2007. City as Organism. Hamshahri online.

7. Oldenburg, R. 1990.The Great Good Place. 
8. Project for Public Spaces (PPS) 2006. Place making for Communities - When Third Places Come.

org.pps.www

9. Oldenburg, R.1990.The Great Good Place.

10. Altman, E. 2003. Environment \& Social Treatment. Shahid Beheshti University, Iran.

11. Oldenburg, R.1990.The Great Good Place. 12. When Third Place Is the Right Place.

www. Homiletiosonline.com

13. Nova, N.2004. How the environment supports social and collaborative processes, Physical space and collaboration.

14. Coburn, B. 2007. Cafés of community: the Starbucks principle,Strategic Adult Ministries Journal (Vol. 18, No. 5, Issue 145).

15. Shayan Rad, R. 2005. Tehran's Traditional coffeehouses \& Coffeehouses Syndicates.

16. Hasan Beigi, M. 2003. The Old Tehran. GHoghnoos Publisher. Tehran, Iran.

17. Mashhadi zade dehaghani, N.2002. Analyzing features of urban planning in Iran. Elm \& Sanat University, Tehran, Iran.

18. Arbab, P. 2007. City as Organism. Hamshahri online. 